\title{
Hepatic Fibrosis Is Enhanced and Accompanied by Robust Oval Cell Activation after Chronic Carbon Tetrachloride Administration to Egr-1-Deficient Mice
}

\author{
Michele T. Pritchard* and Laura E. Nagy ${ }^{\star \dagger}$ \\ From the Departments of Pathobiology, ${ }^{*}$ and Gastroenterology, ${ }^{\dagger}$ \\ Cleveland Clinic, Cleveland, Obio
}

\begin{abstract}
The transcription factor early growth response (Egr)-1 regulates the expression of genes required for execution of the wound healing response. Multiple cycles of injury, coupled to incomplete wound healing, lead to fibrosis. Therefore, we hypothesized that Egr-1 is required for the development of hepatic fibrosis. To test this hypothesis, we exposed wildtype and $\operatorname{egr}-1^{-/-}$mice to acute or chronic carbon tetrachloride $\left(\mathrm{CCl}_{4}\right)$. Acute $\mathrm{CCl}_{4}$ exposure established a profibrotic milieu in the liver, including activation of hepatic stellate cells as well as expression of type 1 collagen genes and tissue inhibitor of matrix metalloproteinase 1 in both wild-type and $\operatorname{egr}-1^{-/-}$mice. This response was exacerbated in egr-1 $1^{-/-}$mice. After chronic $\mathrm{CCl}_{4}$ exposure, hepatic fibrosis was established in both genotypes; however, the fibrotic response was profoundly worsened in Egr-1-deficient mice. Importantly, enhanced fibrosis in egr-1 ${ }^{-/-}$ mice was accompanied by a robust activation of the oval cell response, suggesting more severe liver injury and/or reduced hepatocyte proliferation when compared with wild-type mice. Hepatic expression of genes indicative of oval cell activation, as well as the number of cells expressing A6, a mouse oval cell marker, was greater in egr-1 $1^{-/-}$mice. Taken together, these data reveal novel roles for Egr-1 as a negative regulator of both $\mathrm{CCl}_{4}$-induced hepatic fibrosis and the oval cell response. (Am J Pathol 2010, 176:2743-2752; DOI: 10.2353/ajpath.2010.091186)
\end{abstract}

The wound healing response is a rapidly induced and finely orchestrated series of cellular and molecular events necessary for prompt tissue repair and reinstatement of tissue/organ integrity after injury. ${ }^{1}$ Perturbations in this system lead to aberrant tissue repair. In the case of prolonged exposure to injury, tissue fibrosis, defined by exces- sive extracellular matrix (ECM) deposition, is established. Liver fibrosis is a common end point of chronic hepatic diseases of all etiologies. ${ }^{2,3}$ Although there has been significant progress in defining the roles of the many cell types, soluble mediators and transcription factors that contribute to fibrosis and its resolution in animal models, these advances have not yet led to improvements in the therapeutic arsenal available for patients with fibrosis or cirrhosis. Indeed, liver transplant remains the only viable treatment option for the burgeoning population of patients with fibrosis and is hampered by a limited supply of available organs. ${ }^{4}$

Early growth response (Egr)-1 (also known as NGFI-A, zif268, TIS8, and Krox24) is an 80- to 82-kDa transcription factor and prototypic member of the early growth response gene family. ${ }^{5}$ Egr-1 is an immediate early gene induced in response to a number of growth and differentiation factors and in response to tissue injury. ${ }^{5-10}$ Its swift induction and rapid decay place Egr-1 at a position to induce the expression of genes necessary for rapid yet transient responses to many forms of acute cellular stress. Using its three zinc-finger DNA binding domain, Egr-1 binds to $\mathrm{G} / \mathrm{C}$-rich regions found in the promoters of genes involved in inflammation (tumor necrosis factor [TNF] $\alpha$, intercellular adhesion molecule-1) and also indirectly affects the expression of other inflammatory mediators (macrophage inflammatory protein-2, monocyte chemoattractant protein [MCP]-1). ${ }^{11-13}$ Egr-1 is characterized as a 'master regulator' of inflammatory gene expression in mouse models of ischemia/reperfusion, endotoxemia, ethanol-induced fatty liver injury, and acute hepatitis., ${ }^{6,8-10}$

Egr-1 expression is also a component of the wound healing response. ${ }^{14-16}$ Successful repair after injury involves inflammation, coagulation, angiogenesis, new tissue forma-

Supported by National Institutes of Health/National Institute on Alcohol Abuse and Alcoholism grants AA015833 and AA017918 (to M.T.P.) and AA0138868 (to L.E.N.).

Accepted for publication February 12, 2010

Supplemental material for this article can be found on http://ajp. amjpathol.org.

Address reprint requests to Michele T. Pritchard, Ph.D., Department of Pathobiology - NE40, Cleveland Clinic, 9500 Euclid Avenue, Cleveland, $\mathrm{OH}$ 44195. E-mail: pritchm@ccf.org 
tion, and ECM remodeling/scarring. ${ }^{1}$ Egr-1 contributes to this process by regulating genes involved in coagulation (tissue factor, plasminogen activator inhibitor-1), ECM deposition and metabolism (transforming growth factor $\beta$, fibroblast growth factor-2, type 1 collagen, matrix metalloproteinase 14, platelet-derived growth factor A and B, thrombospondin-1, and fibronectin), cell division (p53 and cell division cycle protein 20 homolog [Cdc20]) and angiogenesis (vascular endothelial growth factor). ${ }^{17-25}$ This broad array of gene expression suggests that Egr-1 has the ability to affect the wound healing response of many, if not all, cell types in a given tissue. For example, in the liver, Egr-1 could potentially promote hepatic stellate cell (HSC) activation via regulation of platelet-derived growth factor, endothelial cell proliferation by vascular endothelial growth factor, and hepatocyte proliferation by Cdc20. Indeed, Egr1-regulated expression of Cdc20 is required for hepatocyte proliferation in response to partial hepatectomy. ${ }^{20}$ Although transient, regulated expression of these gene products is required for appropriate wound healing responses; chronic expression of repair-associated genes is associated with the development of fibrosis.

Despite the key regulatory role that Egr-1 plays in the timely expression of genes induced during the tissue response to injury, the role of Egr-1 in hepatic fibrosis is not known. Because Egr-1 regulates the expression of many profibrotic genes, we hypothesized that Egr-1 is required for hepatic fibrosis in response to chronic injury and that Egr1-deficient mice would be protected from hepatotoxin-induced fibrosis. To test this hypothesis, we used the wellcharacterized carbon tetrachloride $\left(\mathrm{CCl}_{4}\right)$-induced hepatic fibrosis mode ${ }^{26}$ in both wild-type and egr-1 ${ }^{-1-}$ mice. We predicted that, in the absence of Egr-1, fibrosis would be attenuated by the contribution of Egr-1 to expression of many genes associated with the wound healing response. To our surprise, hepatic fibrosis in egr-1-1- mice after chronic $\mathrm{CCl}_{4}$ was enhanced and recovery delayed compared with wild-type mice. In addition, chronic $\mathrm{CCl}_{4}$ exposure in egr- $1^{-1-}$ mice induced a striking activation of the hepatic progenitor cell or 'oval cell' compartment. Oval cell activation is not typically associated with hepatocyte replenishment after $\mathrm{CCl}_{4}$ exposure. Undamaged hepatocytes are widely appreciated to enter the cell cycle and recover lost liver mass in this model; only when liver injury is severe and/or hepatocyte proliferation is attenuated will oval cells participate in liver regeneration. ${ }^{27}$ To our knowledge, this is the first study to report a robust progenitor cell response during hepatic recovery after chronic $\mathrm{CCl}_{4}$ exposure. Our recent work (unpublished data) support the hypothesis that very severe liver injury in egr- $1^{-1-}$ mice after an initial exposure to $\mathrm{CCl}_{4}$ contributes to oval cell activation after chronic $\mathrm{CCl}_{4}$ exposure.

\section{Materials and Methods}

\section{Materials}

$\mathrm{CCl}_{4}$ and olive oil were purchased from Sigma-Aldrich (St. Louis, MO). All primers for real-time reverse-transcription PCR were synthesized by Integrated DNA Tech- nologies (Coralville, IA). Primary antibodies were purchased from the following companies: Cytochrome P450 2E1 (CYP2E1) Research Diagnostics, Inc (Flanders, NJ); Hsc 70 Santa Cruz (Santa Cruz, CA); $\alpha$ smooth muscle actin ( $\alpha$ SMA, clone 1 A6 Sigma-Aldrich, St. Louis, MO); A6 antibody was a generous gift from Dr. Valentina Factor $(\mathrm{NIH} / \mathrm{NCl})$.

\section{Animals}

Female wild-type (C57BL/6NTac) or egr-1 ${ }^{-1-}$ (B6.129-

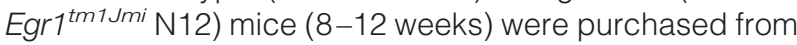
Taconic Farms (Germantown, NY). The egr-1 $1^{-1-}$ mouse was originally developed in the laboratory of Jeffrey Milbrandt. ${ }^{28,29}$ Animals were housed in standard microisolator cages and fed standard laboratory chow (rodent diet \#2918, Harlan-Teklad, Madison, WI). All animal procedures were approved by the Cleveland Clinic Institutional Animal Care and Use Committee. The following numbers of animals were used in the acute studies: olive oil, 4 wild-type and 4 egr-1-1- mice; 18 hours, 5 wild-type and 5 egr- $1^{-1-}$ mice; 72 hours, 5 wild-type and 5 egr-1-1- mice. The following numbers of animals were used in chronic $\mathrm{CCl}_{4}$ experiments: olive oil, 7 wild-type and 6 egr-1-1- mice; 3 days, 9 wild-type and 6 egr- $1^{-1-}$ mice; 7 days, 5 wild-type and 5 egr-1 $1^{-1-}$ mice.

\section{$\mathrm{CCl}_{4}$ Administration and Sample Collection}

In both acute and chronic $\mathrm{CCl}_{4}$ studies, $\mathrm{CCl}_{4}$ was prediluted 1:3 in olive oil before administration; controls received injections of olive oil alone. For acute $\mathrm{CCl}_{4}$ studies, mice received a single dose at $1 \mu \mathrm{l} / \mathrm{g}$ body weight of prediluted (1:3 in olive oil) $\mathrm{CCl}_{4}$ administered by intraperitoneal injection using $100 \mu \mathrm{l}$ Hamilton syringes and $26 \mathrm{G}$ $5 / 8$ inch needles. The dose was well tolerated by wildtype and egr-1 $1^{-1-}$ mice. Both genotypes had lost $1 \mathrm{~g}$ of body weight relative to olive oil controls 18 hours after the $\mathrm{CCl}_{4}$ injection. This weight loss was completely recovered in wild-type mice by 72 hours; egr-1 $1^{-1-}$ mice recovered some but not all of the weight loss by 72 hours. For chronic $\mathrm{CCl}_{4}$ studies, mice received a total of 10 injections (2 injections each week on Tuesdays and Fridays) over 5 weeks. Mice were ramped up to the full dose of $\mathrm{CCl}_{4}$ over two doses (first injection at $0.25 \mu \mathrm{l} / \mathrm{g}$ body weight, the second at $0.5 \mu \mathrm{l} / \mathrm{g}$ body weight). The third through tenth injections were administered at the full 1 $\mu \mathrm{l} / \mathrm{g}$ body weight dose. As in the acute studies, each dose was prediluted (1:3) in olive oil before administration. Injections were given on the opposite side of the peritoneal cavity from the previous injection. Wild-type mice tolerated the chronic $\mathrm{CCl}_{4}$ administration paradigm well; egr-1 $1^{-1-}$ mice were less resilient to subsequent doses of $\mathrm{CCl}_{4}$ by the end of the third week. The difference in tolerance to the chronic treatment paradigm was paralleled by differences in body weight at 3 and 7 days after completion of $\mathrm{CCl}_{4}$ exposure (see supplemental Figure $\mathrm{S} 1$ at $h$ ttp://ajp.amjpathol.org). In the acute studies, animals were sacrificed 18 and 72 hours after $\mathrm{CCl}_{4}$ administration. In the chronic studies, animals were sacrificed 
Table 1. Real-Time PCR Primer Sequences for Genes of Interest (GOI)

\begin{tabular}{|c|c|c|c|}
\hline GOI & GenBank accession & Primer bank* accession & Primer sequences \\
\hline $18 S$ & X00686 & NA & F : 5'-ACGGAAGGGCACCACCAGGA-3' \\
\hline Egr-1 & NM_007913 & $6681285 a 2$ & $\begin{array}{l}\mathrm{F}: 5^{\prime}-\text { AGCGAACAACCCTATGAGCAC-3" } \\
\mathrm{R}: 5^{\prime}-\mathrm{TCGTTTGGCTGGGATAACTCG-3"}\end{array}$ \\
\hline$\alpha S M A$ & NM_007392 & $6671507 a 1$ & $\begin{array}{l}\mathrm{F}: 5^{\prime}-\text { GTCCCAGACATCAGGGAGTAA-3' } \\
\mathrm{R}: 5^{\prime}-\mathrm{TCGGATACTTCAGCGTCAGGA-3'}\end{array}$ \\
\hline desmin & NM_010043 & $33563250 a 1$ & $\begin{array}{l}\mathrm{F}: 5^{\prime}-\text { GTGGATGCAGCCACTCTAGC-3' } \\
\mathrm{R}: 5^{\prime}-\mathrm{TTAGCCGCGATGGTCTCATAC-}{ }^{\prime}\end{array}$ \\
\hline COL1A1 & NM_007742 & NA & $\begin{array}{l}\mathrm{F}: 5^{\prime}-\text { CAAGAACAGCAACGAGTACCG-3' } \\
\mathrm{R}: 5^{\prime}-\text { GTCACTGGTCAACTCCAGCAC-3, }\end{array}$ \\
\hline COL1A2 & NM_007743 & $6680980 a 2$ & $\begin{array}{l}\mathrm{F}: 5^{\prime}-\text { GGTGAGCCTGGTCAAACGG-3' } \\
\mathrm{R}: 5^{\prime}-\text { ACTGTGTCCTTTCACGCCTTT-3' }\end{array}$ \\
\hline CTGF & NM_010217 & 6753878a1 & $\begin{array}{l}\mathrm{F}: 5^{\prime} \text {-GGGCCTCTTCTGCGATTTC-3' } \\
\mathrm{R}: 5^{\prime}-\text { ATCCAGGCAAGTGCATTGGTA-3' }\end{array}$ \\
\hline TIMP1 & NM_011593 & $6755795 a 1$ & $\begin{array}{l}\mathrm{F}: 5^{\prime}-\text { GCAACTCGGACCTGGTCATAA-3' } \\
\mathrm{R}: 5^{\prime}-\text { CGGCCCGGATGAGAAACT-3' }\end{array}$ \\
\hline$A F P$ & NM_007423 & $31982513 a 2$ & $\begin{array}{l}\mathrm{F}: 5^{\prime} \text {-AACTCTGGCGATGGGTGTTTA-3' } \\
\mathrm{R}: 5^{\prime} \text {-ACACTGATGTCTTTCCACTCCA-3' }\end{array}$ \\
\hline Thy-1 & NM_009382 & $6678347 a 1$ & 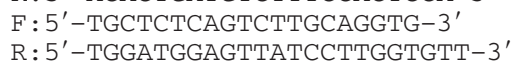 \\
\hline HGF & X84046 & $4165287 \mathrm{~A} 1$ & $\begin{array}{l}\mathrm{F}: 5^{\prime}-\text { ATGTGGGGGACCAAACTTCTG-3' } \\
\mathrm{R}: 5^{\prime}-\text { GGATGGCGACATGAAGCAG-3' }\end{array}$ \\
\hline c-met & NM_008591 & 6678868a1 & 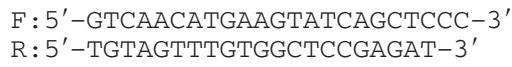 \\
\hline TWEAK & NM_011614 & $33438584 a 1$ & $\begin{array}{l}\mathrm{F}: 5^{\prime} \text {-CCGCCAGATTGGGGAATTTAC-3' } \\
\mathrm{R}: 5^{\prime}-\text { AGTCCAAAGTAGGTTAGGAAGGG-3' }\end{array}$ \\
\hline Fn14 & NM_013749 & $7305059 a 1$ & $\begin{array}{l}\mathrm{F}: 5^{\prime}-\text { GTGTTGGGATTCGGCTTGGT-3' } \\
\mathrm{R}: 5^{\prime}-\text {-GTCCATGCACTTGTCGAGGTC-3' }\end{array}$ \\
\hline MCP1 & NM_011333 & NA & $\begin{array}{l}\mathrm{F}: 5^{\prime} \text {-AAGTCCCTGTCATGCTTCTG-3' } \\
\mathrm{R}: 5^{\prime} \text {-TCTGGACCCATTCCTCTTG-3' }\end{array}$ \\
\hline
\end{tabular}

NA, indicates not applicable

*, Primer Bank, http://pga.mgh.harvard.edu/primerbank/

at 3 and 7 days after the final $\mathrm{CCl}_{4}$ exposure. At the time of sacrifice, mice were weighed, and once anesthetized, blood was collected from the posterior vena cava. Plasma was separated from whole blood and stored at $-80^{\circ} \mathrm{C}$. Mice were then euthanized, while under anesthesia, by exsanguination. Livers were removed, weighed, and portions fixed in formalin, frozen in Optimal Cutting Temperature medium (Sakura Finetek USA, Torrance, $\mathrm{CA})$, snap frozen in liquid nitrogen, or stored in RNAlater (Ambion, Austin, TX) for further analysis.

\section{Liver Histology and Assessment of Fibrosis}

For histological analysis, formalin-fixed tissues were paraffin-embedded, sectioned (5 $\mu \mathrm{m})$, and stained with hematoxylin and eosin (H\&E), Sirius red, or Masson trichrome. Slides were coded before initial examination and viewed by two separate individuals. Quantification of Sirius red staining was performed using ImagePro plus software (Media Cybernatics, Silver Spring, MD).

\section{Real-Time RT-PCR}

Total RNA was isolated from liver and $4 \mu \mathrm{g}$ of total hepatic RNA was reverse transcribed. ${ }^{9}$ Real-time PCR amplification was performed using Brilliant SYBR Green QPCR Master Mix (Stratagene, La Jolla, CA) and genespecific primers (Table 1) in an Mx3000p PCR machine (Stratagene). Reaction volumes and thermal cycle parameters were as previously described. ${ }^{9}$ The relative amount
mRNA was determined using the comparative threshold (Ct) method by normalizing target cDNA Ct values to that of 18S; $18 \mathrm{~S} \mathrm{Ct}$ values did not change from baseline values at time points after $\mathrm{CCl}_{4}$ used in these studies. Fold induction ratios were calculated relative to basal conditions for each genotype using the formula: $2^{-\Delta \Delta C t}$.

\section{Liver Homogenate Preparation, Electrophoresis, and Immunoblotting}

Liver homogenates were prepared and protein concentrations determined for immunoblotting. ${ }^{30}$ Thirty-five micrograms of protein were resolved on $15 \%$ polyacrylamide gels and transferred to Polyvinylidene fluoride membranes. Membranes were probed with antibodies specific for CYP2E1 and Hsc 70 (loading control).

\section{$\alpha$ Smooth Muscle Actin Immunolocalization}

Formalin-fixed paraffin embedded liver sections (5 $\mu \mathrm{m})$ were deparaffinized and hydrated consecutively in 100\% twice, $95 \%$ and $70 \%$ ethanol followed by 2 washes in distilled water. Protein epitopes were unmasked using citrate buffer incubation at $95-100^{\circ} \mathrm{C}$ for 20 minutes in an 1100 watt microwave using a pressure cooker (Nordic Ware, Minneapolis, MN). After heat treatment, the sections were allowed to cool at room temperature for an additional 20 minutes. Endogenous peroxidase activity and avidin/biotin were quenched using 3\% hydrogen 
peroxide $\left(\mathrm{H}_{2} \mathrm{O}_{2}\right)$ and appropriate avidin and biotin blocking reagents (Vector Laboratories, Inc., Burlingame, CA), respectively. Serum-containing blocking reagents from the Mouse on Mouse kit (Vector Labs) were used per the manufacturer's instructions before incubation with the mouse $\alpha$ SMA antibody (1:1600). The horseradish peroxidase-conjugated secondary antibody was used as outlined in the Mouse on Mouse kit. After washing away unbound secondary antibody, sections were incubated with Avidin-Biotin Complex reagents followed by incubation with diaminobenzamidine for 1 minute. Sections were then washed in cold running tap water for 5 minutes and then immersed in hematoxylin (DAKO, Carpinteria, CA) for 5 minutes before another 5-minute wash in cold running water. Finally, sections were dehydrated and preserved using Permount (Sigma-Aldrich) and glass coverslips. No immunostaining was seen in sections incubated with blocking reagent alone in the absence of primary antibody.

\section{A6 Immunolocalization and Quantification}

A6 is a marker for mouse oval cells. ${ }^{31}$ Five-micrometer frozen sections from livers embedded in Tissue-Tek Optimal Cutting Temperature Compound (Sakura Finetek USA, Torrance, CA) were fixed in methanol:acetone (1:1) for 10 minutes and then air dried for 10 minutes. Endogenous peroxidase in liver sections was quenched by emersion in $3 \% \mathrm{H}_{2} \mathrm{O}_{2}$ for 2 minutes. After blocking in 10\% normal goat serum, sections were incubated with the anti-A6 antibody (1:40 dilution in 10\% normal goat serum) for 60 minutes at room temperature in a humidified chamber. After two 5-minute washes in Tris-buffered saline (TBS), sections were incubated with an horseradish peroxidase-conjugated goat-anti-rabbit secondary antibody. After two additional washes in TBS, sections were incubated with diaminobenzamidine for 5 minutes, rinsed in TBS, and then distilled water and stained with hematoxylin for 5 minutes. After dehydration in a graded series of ethanols and xylene substitute, sections were preserved using Permount (Sigma-Aldrich) and glass coverslips. A6-positive cells were counted in four $\times 400$ fields per slide by blinded individuals. The A6 antibody recognizes biliary epithelial cells found in bile caniculi of the portal tracts as well as oval cells. ${ }^{31}$ Therefore, only A6positive cells found in the parenchyma in areas separate from portal tracts were enumerated.

\section{Statistical Analysis}

Values reported are means \pm SEM. Because of the limited number of age-matched egr-1-1- mice, data were collected from several different experiments. The data were analyzed by general linear models procedure (SAS, Carey, NC) followed by least square means analysis of differences between groups, blocking for experiment effects when data from more than one experiment were used in any given data set. Data were log transformed to obtain a normal distribution, if necessary. Comparisons between data sets with $P$ values of less than 0.05 were considered significant.

\section{Results}

Egr-1 Deficiency Was Associated with Enhanced Hepatic Stellate Cell Activation after Acute $\mathrm{CCl}_{4}$ Exposure

A single $\mathrm{CCl}_{4}$ exposure in mice and rats activates HSCs, the cell type largely responsible for excessive ECM deposition and fibrosis after repeated $\mathrm{CCl}_{4}$ exposure. ${ }^{32}$ Indices of HSC activation and hepatic fibrogenesis after acute exposure to $\mathrm{CCl}_{4}$ can be used to predict the severity of fibrosis after chronic exposure to $\mathrm{CCl}_{4}$. Hepatic $\alpha \mathrm{SMA}$ and desmin, markers associated with HSC activation, were increased in livers from wild-type and egr-1-1mice 72 hours after acute $\mathrm{CCl}_{4}$ exposure; this increase was greater in livers from mice deficient in Egr-1 (Figure 1, A and B). $\alpha S M A$ protein expression paralleled the mRNA data; immunoreactive $\alpha$ SMA was greater in livers from egr-1 $1^{-1-}$ mice compared with wild-type mice (Figure 1C). Activated HSCs produce type I collagen molecules, the predominate collagen associated with liver fibrosis. ${ }^{3}$ Seventy-two hours after acute $\mathrm{CCl}_{4}$ exposure, hepatic mRNA accumulation of collagen $1 \alpha 1$ (COL1A1) and collagen $1 \alpha 2$ (COL1A2) was increased in both strains of mice; however, this increase was fivefold greater in livers from egr-1 $1^{-1-}$ mice (Figure 1, D and E, respectively). Associated with increased activation of HSC and production of type I collagen molecules in egr-1 ${ }^{-1-}$ mice was increased expression of connective tissue growth factor (CTGF), a pro-fibrotic molecule, and tissue inhibitor of matrix metalloproteinase-1, an inhibitor of matrix degradation (Figure 1, F and $G$, respectively) compared with wild-type mice. Expression of cytochrome P450 2E1 (CYP2E1), the enzyme required for $\mathrm{CCl}_{4}$ bioactivation and $\mathrm{CCl}_{4}$-induced liver injury and fibrosis, ${ }^{33}$ was not different between wild-type and egr-1-1- mice after acute $\mathrm{CCl}_{4}$ exposure (unpublished data).

\section{Exacerbated Fibrosis after Chronic $\mathrm{CCl}_{4}$ Exposure in egr- $1^{-1-}$ Mice}

In animal models of acute injury, Egr-1 expression is robust, but transient. ${ }^{8,34}$ After chronic $\mathrm{CCl}_{4}$ exposure, hepatic Egr-1 mRNA was increased over baseline at 3 and 7 days post $\mathrm{CCl}_{4}$ exposure in wild-type mice (Figure 2). However, the level of expression was lower than after acute $\mathrm{CCl}_{4}$ exposure (unpublished data). These data suggested that low, but sustained, Egr-1 expression was characteristic of chronic $\mathrm{CCl}_{4}$-induced liver injury.

Repeated exposure of mice to $\mathrm{CCl}_{4}$ over several weeks induces excessive ECM deposition in liver which associated with fibrosis. ${ }^{26}$ To determine the effect Egr-1 deficiency had on development of hepatic fibrosis, we exposed wild-type and egr-1 ${ }^{-1-}$ mice to $\mathrm{CCl}_{4}$ for a total of 5 weeks. Sirius red staining of ECM demonstrated established fibrosis in both genotypes. The quantity of ECM 
A

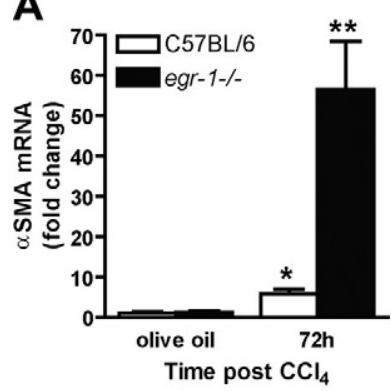

B

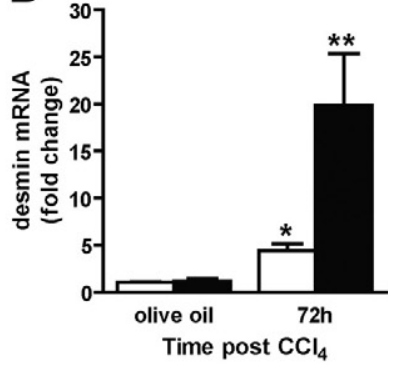

C

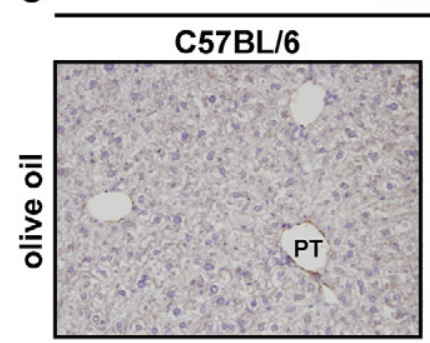

$\alpha$ SMA
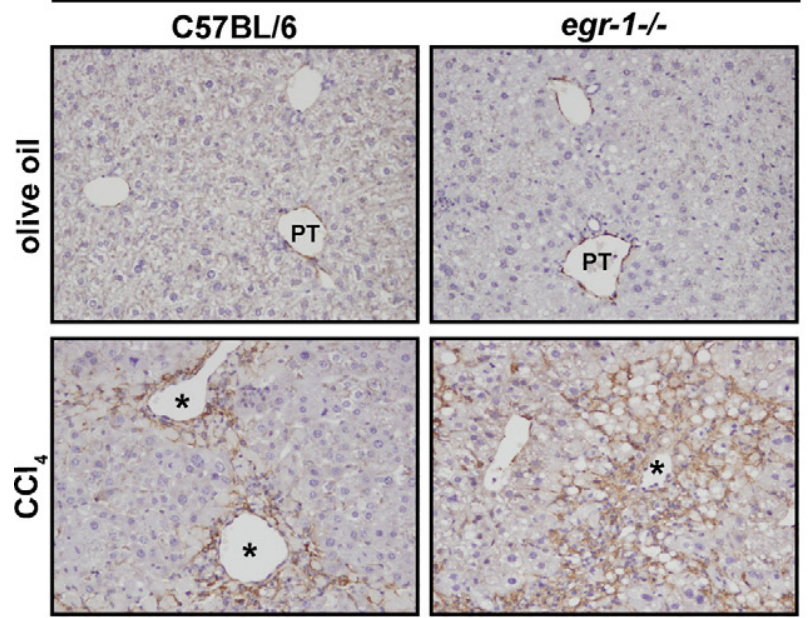

D

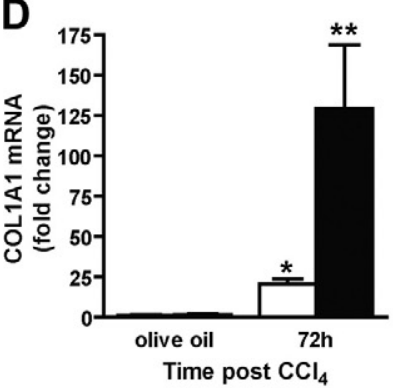

$E$
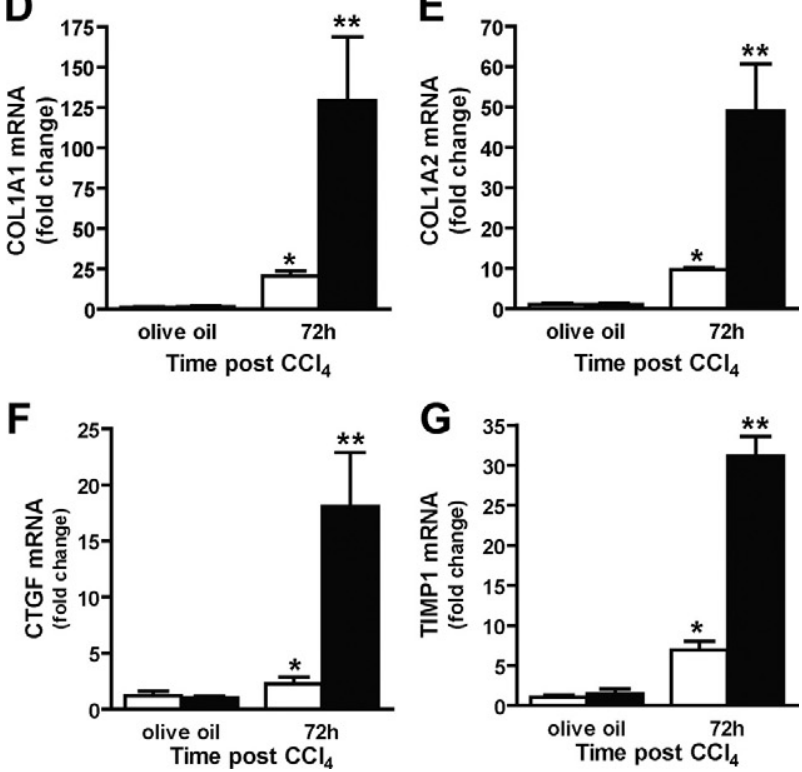

Figure 1. HSC activation after acute $\mathrm{CCl}_{4}$ administration. Seventy-two hours after a single olive oil or $\mathrm{CCl}_{4}$ injection, biomarkers of HSC activation were measured in wild-type and $e g r-1^{-/-}$mice. Hepatic (A) $\alpha \mathrm{SMA},(\mathbf{B})$ desmin (D) COL1A1, (E) COL1A2, (F) CTGF, and (G) tissue inhibitor of matrix metalloproteinase- 1 mRNA accumulation was determined by real-time PCR using gene specific primers (Table 1). Data are expressed as fold change over olive oil controls for each genotype after normalization to $18 \mathrm{~S}$ (housekeeping gene). The data are means \pm SEM, $n=4$ to 6 per experimental condition. There is a significant change in gene expression after $\mathrm{CCl}_{4}$ when compared with genotype-specific olive oil control $\left({ }^{*} P<0.05\right)$. There is a significant change in gene expression after $\mathrm{CCl}_{4}$ compared with genotype-specific olive oil control and between genotypes at the indicated time point $\left({ }^{* * *} P<0.05\right)$. C: Immunolocalization of hepatic $\alpha$ SMA protein from olive oil or $\mathrm{CCl}_{4}$-treated mice, $\times 200$ magnification. Images are representative of $n=4$ to 6 per experimental group. Asterisk in image denotes the central vein; PT denotes portal tract.

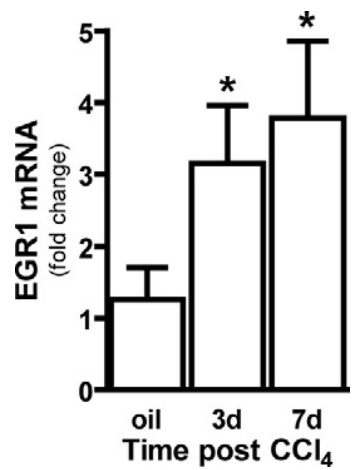

Figure 2. Egr-1 expression was prolonged after chronic $\mathrm{CCl}_{4}$ exposure in wild-type mice. Wild-type mice were treated with olive oil or $\mathrm{CCl}_{4}$ for five weeks. Mice were euthanized at the time points indicated, their livers harvested and analyzed for hepatic Egr-1 mRNA accumulation by real-time PCR. Data are means \pm SEM of $n=5$ to 10 per experimental group. There is a significant difference compared with olive oil controls $\left({ }^{*} P<0.05\right)$.

was greater in Egr-1-deficient mice compared with wildtype mice both 3 and 7 days after the final $\mathrm{CCl}_{4}$ exposure and was predominantly bridging in morphology (Figure 3, $\mathrm{A}-\mathrm{H}$, quantification in I). In addition, the pattern of ECM deposition differed between wild-type and egr-1 ${ }^{-1-}$ mice. Fibrotic septa in wild-type mice were tight distinct bands between hepatic chords, minimizing the total area of the liver affected by ECM deposition (Figure 3, A and E, C and G). In contrast, fibrotic septa in egr-1 ${ }^{-1-}$ mice were diffuse and punctuated by areas of Sirius red-negative tissue (Figure 3, B and F, D and H). Differences in hepatic CYP2E1 expression were not observed between genotypes at any time point examined after chronic $\mathrm{CCl}_{4}$ exposure (see supplemental Figure S2 at http://ajp.amjpathol.org).

\section{Enhanced Activation of the Oval Cell Compartment in egr-1 $1^{-1-}$ Mice after Chronic $\mathrm{CCl}_{4}$}

Masson's trichrome staining was used to visualize localization of ECM components (in bright blue) within the context of liver architecture (in shades of dark purple and pink) to further investigate the morphology of the diffuse ECM deposition in livers from egr-1 ${ }^{-1-}$ mice after chronic $\mathrm{CCl}_{4}$ exposure (Figure 4). The diffuse nature of ECM staining in egr-1-1- mice revealed by Sirius red staining was attributable, at least in part, to the interruption of the fibrotic septa by large numbers of small cells situated singly or in small groups within the collagen fibers at both time points after chronic $\mathrm{CCl}_{4}$ (Figure 4, A and B); these cells were not present in the livers of wild-type mice. The nuclear morphology of a portion of the cells was consistent with the presence of a hepatic progenitor cell type called oval cells (Figure 4, enlarged insets). The putative oval cells were not active HSC as they were not labeled by immunostaining for $\alpha \mathrm{SMA}$ (Figure 5). $\alpha \mathrm{SMA}$-positive cells were limited to uninterrupted areas between hepatic chords in wild-type mice, whereas diffuse and extensive $\alpha$ SMA staining found in livers from egr-1-1- mice was localized predominately to the perimeter of hypercellular 
Sirius Red
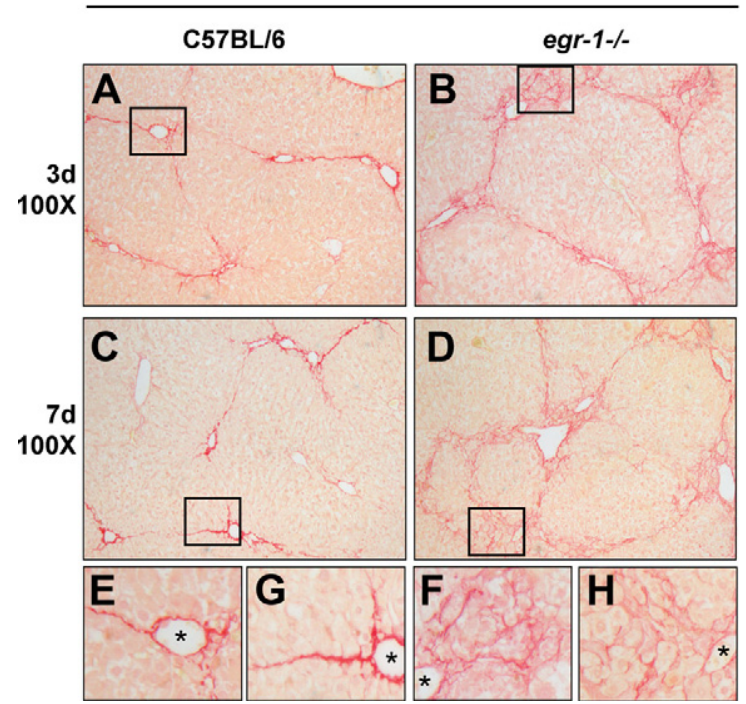

Figure 3. Hepatic fibrosis after chronic $\mathrm{CCl}_{4}$ exposure. Wild-type and $e g r-1^{-/-}$mice were treated with olive oil (not shown) or $\mathrm{CCl}_{4}$ for five weeks. Three (A and $\mathbf{B}$ ) and seven days (C and D) after final injection, mice were sacrificed and their livers removed, processed, and stained with Sirius red to visualize collagen fiber/ECM deposition. Outlined areas in A-D are enlarged to illustrate differences in the pattern of ECM deposition and are denoted in $\mathbf{E}-\mathbf{H}$, respectively. Asterisks in enlarged images denote central veins. Images are representative of $n=4$ to 5 mice per experimental group, and two $\times 100$ fields per mouse. I: Morphometric assessment of total Sirius red density in livers from mice three and seven days after cessation of chronic $\mathrm{CCl}_{4}$ exposure. Data represent means \pm SEM, $n=4$ to 5 mice per experimental group and two $\times 100$ fields per mouse. There is a significant difference when compared with olive oil control for same genotype $\left({ }^{*} P<0.05\right)$. There is a significant difference when compared to wild-type at same time point $(* * P<0.05)$ regions that contained cells with oval cell morphology (Figure 5).

Hepatic oval cell activation is associated with the expression of a set of genes including $\alpha$ fetoprotein (AFP) ${ }^{35}$ and thymocyte differentiation antigen (Thy) $-1,{ }^{36}$ and

\section{A}

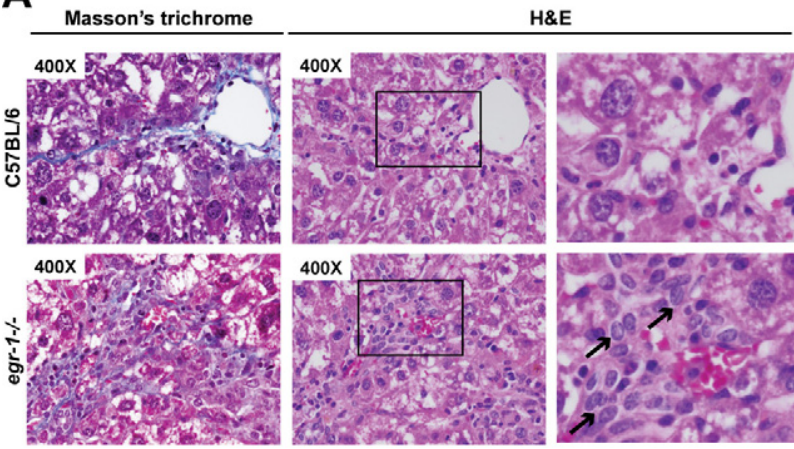

\section{B}

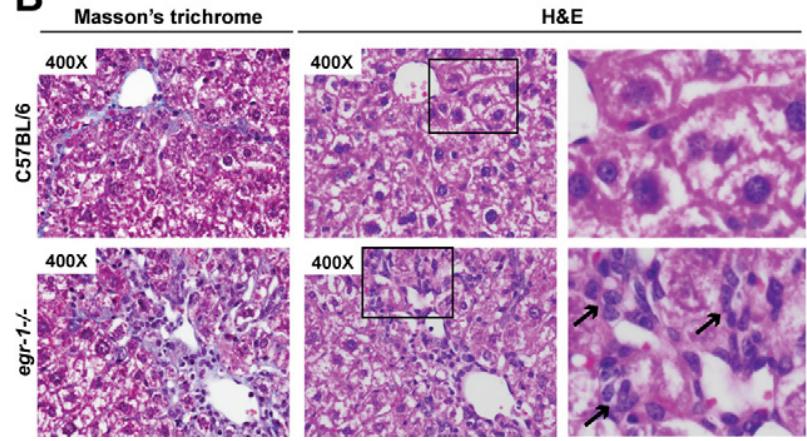

Figure 4. Pronounced cellular hyperplasia in $e g r-1^{-1-}$ mice was associated with diffuse ECM deposition after chronic $\mathrm{CCl}_{4}$ exposure. Wild-type and $e g r-1^{-1-}$ mice were treated with olive oil (not shown) or $\mathrm{CCl}_{4}$ for five weeks. Mice were then sacrificed and their livers removed for histological analysis and ECM deposition analysis by hematoxylin and eosin (H\&E) and Masson's trichrome staining, respectively in serial sections (A) 3 days or (B) seven days after the end of chronic $\mathrm{CCl}_{4}$ exposure. Outlined areas in $\times 400 \mathrm{H} \& \mathrm{E}$ images are enlarged for clarity and reproduced to the right of each $\times 400$ image. Black arrows denote cells whose nuclear morphology is consistent with hepatic oval cells. Images are representative of $n=4$ to 5 mice per experimental group. oval cell growth factors including CTGF, hepatocyte growth factor (HGF), and its receptor c-met, as well as TWEAK and its receptor, Fn14. ${ }^{37,38}$ AFP expression was induced in livers of both wild-type and egr-1 $1^{-1-}$ mice 3 days after final $\mathrm{CCl}_{4}$ exposure, but this increase was sevenfold greater in egr-1-1- mice (Figure 6A). Although AFP levels returned to baseline in wild-type mice at 7 days, AFP remained eightfold over baseline in egr-1 ${ }^{-1-}$ mice (Figure 6A). Hepatic Thy-1 and HGF expression were induced in egr-1 ${ }^{-1-}$ mice, but not in wild-type mice, 3 and 7 days after $\mathrm{CCl}_{4}$ cessation (Figure 6, B and $\mathrm{C}$ ). Along with its profibrotic roles, ${ }^{39}$ CTGF is also an important mediator of oval cell activation and migration. ${ }^{40}$ CTGF is expressed in the livers of both wild-type and egr-1 $1^{-1-}$ mice 3 days after $\mathrm{CCl}_{4}$ (Figure 6D). CTGF ex-

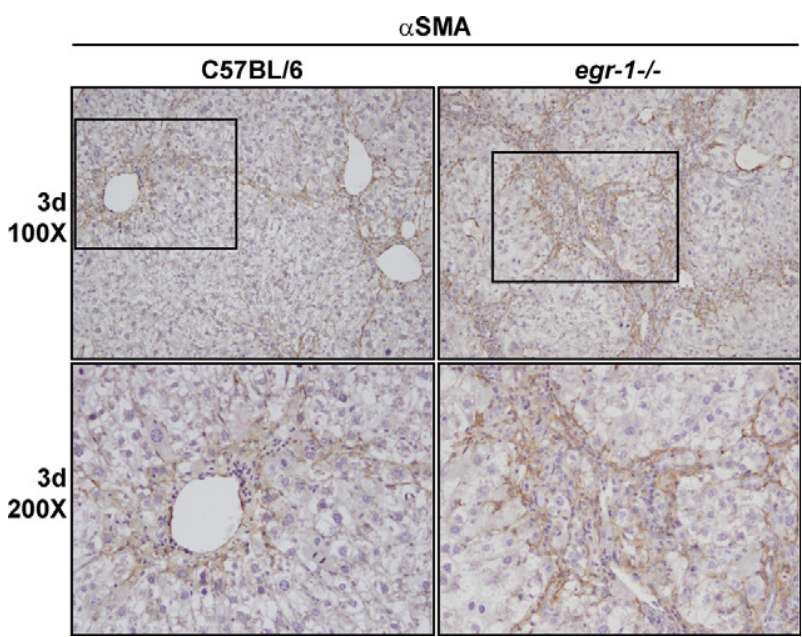

Figure 5. Immunolocalization of $\alpha$ SMA-positive cells in liver after chronic $\mathrm{CCl}_{4}$ exposure. Wild-type and $e g r-1^{-/-}$mice were treated with olive oil (not shown) or $\mathrm{CCl}_{4}$ for five weeks. Mice were sacrificed and their livers removed and processed for $\alpha \mathrm{SMA}$ immunohistochemistry to visualize activated HSC three days after the final injection. Outlined areas in $\times 100$ images were photographed again at $\times 200$ to better illustrate localization of $\alpha$ SMA-positive cells in relation to hypercellular areas observed in livers from $e g r-1^{-1}$ mice, and the lack of this pattern in livers from wild-type mice. Images are representative of $n=4$ to 5 mice per experimental group. 
A
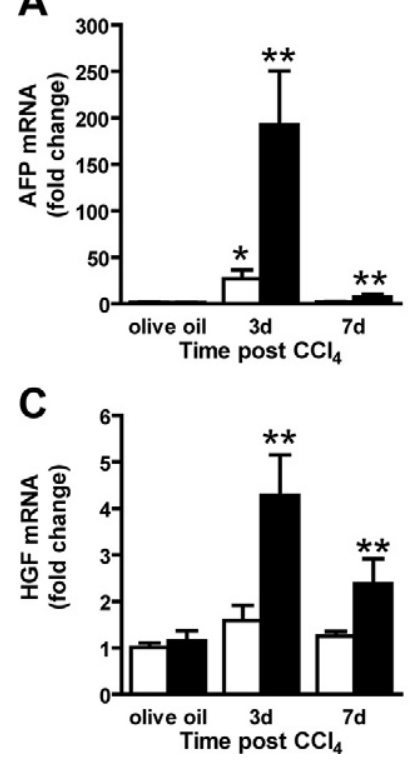

B

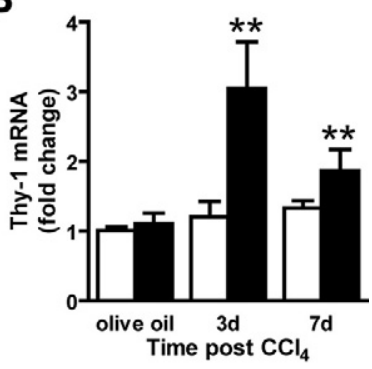

D

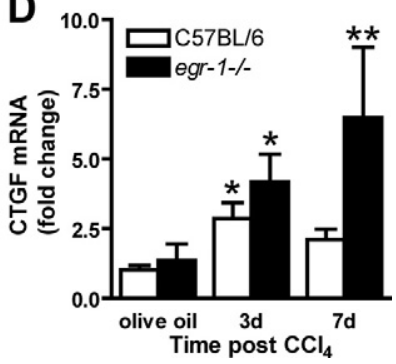

Figure 6. Expression of mRNAs associated with oval cell activation after chronic $\mathrm{CCl}_{4}$ exposure. Wild-type and $e g r-1^{-/-}$mice were treated with olive oil or $\mathrm{CCl}_{4}$ for five weeks. Mice were sacrificed and hepatic expression of $(\mathbf{A})$ AFP, (B) Thy-1, (C) HGF, and (D) CTGF was determined by real-time PCR at the indicated time points. Relative amounts of gene-specific mRNA were calculated using the $2^{-\Delta \Delta \mathrm{Ct}}$ method and results expressed as fold change over olive oil controls for each genotype after normalization to $18 \mathrm{~S}$ (housekeeping gene). The data are means \pm SEM, $n=5$ to 9 mice per experimental group. There is a significant difference in gene expression after $\mathrm{CCl}_{4}$ when compared with genotype-specific olive oil control $\left({ }^{*} P<0.05\right)$. There is a significant difference in gene expression after $\mathrm{CCl}_{4}$ when compared with genotype-specific olive oil control and between genotypes at the indicated time point ( $\left.{ }^{* *} P<0.05\right)$.

pression returns to baseline in wild-type mice 7 days after $\mathrm{CCl}_{4}$ while its expression is maintained in egr-1-1- mice (Figure 6D). There were no detectable changes in expression of HGF receptor c-met or differences in TWEAK and Fn14 expression between wild-type or egr-1 ${ }^{-1-}$ mice (see supplemental Figure S3 at http://ajp.amjpathol.org).

To specifically identify oval cells in the livers of mice after chronic $\mathrm{CCl}_{4}$, we performed immunostaining using the well-characterized A6 antibody, which recognizes an antigen expressed in mouse oval cells. ${ }^{31}$ Livers from olive oil-treated wild-type and egr-1 ${ }^{-1-}$ mice did not exhibit positive $A 6$ staining apart from normal $A 6$ immunolocalization in the portal tract (data not shown). After

chronic $\mathrm{CCl}_{4}$, a few small A6-positive cells were found in clumps outside the portal tracts of wild-type mice (Figure 7A). In contrast, egr-1 $1^{-1-}$ mice had robust A6 immunostaining throughout the liver both 3 and 7 days post cessation of chronic $\mathrm{CCl}_{4}$ exposure (Figure 7A). These cells were larger than those in wild-type mice and were found migrating through the liver parenchyma in chords, as well as in clumps and rings (Figure 7A). Three days after cessation of chronic $\mathrm{CCl}_{4}$, there were fourfold more A6-positive cells per $100 \times$ field in livers from egr-1 ${ }^{-1-}$ mice compared with wild-type mice (Figure 7B). The A6 response in livers of egr-1-1- mice was sustained 7 days after cessation of $\mathrm{CCl}_{4}$; sevenfold more A6-positive cells were found in livers of egr-1-1- mice compared with wild-type mice at this time point (Figure 7B).

\section{Discussion}

The data presented in this article are the first to demonstrate that the transcription factor Egr-1 serves as a brake against fibrogenesis in the liver after chronic $\mathrm{CCl}_{4}$ exposure in mice. Enhanced HSC activation and presence of a profibrotic milieu in livers from Egr-1-deficient mice after a single exposure of $\mathrm{CCl}_{4}$ suggests that perturbations early in the hepatic wound healing response contribute to enhanced fibrosis after multiple exposures to $\mathrm{CCl}_{4}$. Furthermore, this is the first description of robust oval cell activation in mice after chronic $\mathrm{CCl}_{4}$ exposure in the absence of an exogenous antimitotic or other DNA damaging agent. These novel data provide evidence to suggest that Egr-1 is a critical negative regulator of fibrosis and oval cell activation in the liver after hepatotoxicant exposure.

Hepatic fibrosis is the result of repeated cycles of liver injury coupled to incomplete resolution of a normal wound healing response. ${ }^{3}$ Successful injury repair involves an orderly progression of coagulation, inflammation, angiogenesis, tissue formation, and ECM remodeling. ${ }^{1}$ However, during chronic injury, this cycle is interrupted mid-sequence and then re-initiated. This promotes excessive ECM deposition and reduced matrix metabolism and contributes to eventual hepatic dysfunction associated with fibrosis. In addition to fibrosis, prolonged exposure to liver injury is associated with im-
A A6

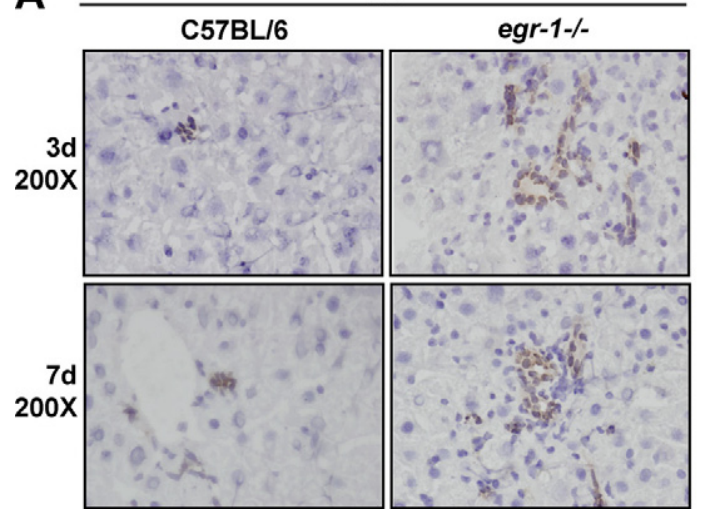

B

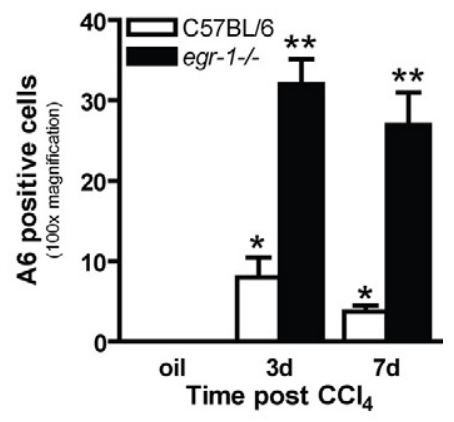

Figure 7. Localization of A6-positive cells in fibrotic livers from wild-type and egr-1 $1^{-1-}$ mice. A: Both three and seven days after cessation of chronic $\mathrm{CCl}_{4}$ exposure, mice were sacrificed and frozen liver sections probed with an antibody to the oval cell-specific antigen, A6, by immunohistochemistry. B: Quantification of A6-positive cells in olive oil-treated mice and three and seven days post chronic $\mathrm{CCl}_{4}$. Data represent means \pm SEM, $n=4$ to 5 mice per experimental group, four $\times 100$ fields per mouse. There is a significant difference in $\mathrm{A} 6$ expression after $\mathrm{CCl}_{4}$ when compared with genotype-specific olive oil control $\left({ }^{*} P<0.05\right)$. There is a significant difference in $\mathrm{A} 6$ expression after $\mathrm{CCl}_{4}$ when compared with genotype-specific olive oil control and between genotypes at the indicated time point $\left({ }^{* *} P<0.05\right)$. 
paired hepatocyte regenerative capacity. When this occurs, activation of the hepatic progenitor cell compartment and progenitor cell-mediated hepatocyte replacement ensues. ${ }^{41}$

Egr-1 is a transcription factor with known roles in the regulation of genes involved in the wound healing response, including those involved in inflammation, coagulation, angiogenesis, cell proliferation, and matrix remodeling. ${ }^{11-13,17-25}$ Egr-1 is induced by lipopolysaccharide, inflammatory cytokines, and reactive oxygen species. These activators are often increased in response to tissue injury ${ }^{5}$ and suggest that Egr-1 is a master regulator of gene expression during wound healing.

Making use of egr-1-1- mice, we identified the transcription factor Egr-1 as a negative regulator of hepatic fibrosis. Enhanced activation of HSC and expression of profibrotic genes after acute $\mathrm{CCl}_{4}$ exposure was associated with enhanced $\mathrm{ECM}$ deposition after chronic $\mathrm{CCl}_{4}$ exposure in egr-1 ${ }^{-1-}$ mice. Wild-type mice transiently lose weight after $\mathrm{CCl}_{4}$ exposure. Body weight is recovered in these mice by 7 days after completion of chronic $\mathrm{CCl}_{4}$ exposure, but not in egr-1 $1^{-1-}$ mice (see supplemental Figure S1 at http://ajp.amjpathol.org). These data support the hypothesis that worsened fibrosis was associated with delayed recovery from $\mathrm{CCl}_{4}$ exposure in egr-1-1- mice. Enhanced hepatic fibrosis in egr-1 ${ }^{-1-}$ mice in this study contrasts with the previously reported role that Egr-1 plays in bleomycin-induced fibrosis of the skin, lung, and unilateral ureteral obstruction-induced fibrosis of the kidney. In these reports, deficiency of Egr-1 attenuates fibrosis and fibrotic markers. ${ }^{16,42}$ Tissue specific differences between the liver and these other organs in the contribution of Egr-1 to chemically-induced fibrosis may stem from the liver's predominant role in toxin metabolism. This is exemplified by the liver's unique capacity to regenerate after toxin-mediated hepatocyte loss, as well as after other forms of liver injury.

Deficiency of Egr-1 is associated with elevated plasma liver function enzyme activity, necrosis, and apoptosis after acute $\mathrm{CCl}_{4}$ exposure (unpublished data). In addition, expression of the Egr-1-regulated proinflammatory cytokine $\mathrm{TNF} \alpha$ is reduced in livers from egr-1-1- mice after acute $\mathrm{CCl}_{4}$ exposure (unpublished data). This is associated with attenuated expression of hepatoprotective genes including inducible nitric oxide synthase, cyclooxygenase 2, and oncostatin M (unpublished data). Ergo, in the absence of appropriate hepatoprotection after acute $\mathrm{CCl}_{4}$ exposure, liver injury is enhanced in mice deficient in Egr-1 and would promote worse fibrosis and delayed recovery from chronic $\mathrm{CCl}_{4}$ exposure. Increased tissue debris in the egr-1 ${ }^{-1-}$ mice could promote enhanced HSC activation ${ }^{3,43}$ and subsequent fibrosis after chronic $\mathrm{CCl}_{4}$ exposure. Increased injury along with excess tissue debris and HSC activation suggest a delay in wound resolution in egr-1 $1^{-1-}$ mice after a single exposure to $\mathrm{CCl}_{4}$. Delayed wound resolution would predispose Egr-1-deficient animals to progressively worse $\mathrm{CCl}_{4}$-induced liver injury and fibrosis with each dose in a chronic (fibrosis-inducing) $\mathrm{CCl}_{4}$ exposure paradigm.
Macrophages play a key role in response to injury, at least in part by acting to clear necrotic tissue. Expression of MCP-1, an Egr-1-regulated macrophage chemoattractant, was reduced in livers from egr-1-1- mice relative to wild-type mice after acute $\mathrm{CCl}_{4}$ exposure (see supplemental Figure S4 at http://ajp.amjpathol.org), consistent with reduced MCP-1 expression in egr-1-1- mice in other animal models of acute injury. ${ }^{8,10}$ Reduced MCP-1 expression could negatively affect recruitment of macrophages to the liver and delay 'wound sterilization' and subsequent liver repair. In support of this hypothesis, liver injury is potentiated and repair is attenuated after acute $\mathrm{CCl}_{4}$ exposure in mice depleted of Kupffer cells, the resident macrophage in the liver, as well as in mice deficient in the MCP-1 receptor, CCR2. ${ }^{44,45}$ Together, these data indicate that recruitment of macrophages is an integral component to wound healing in the liver after $\mathrm{CCl}_{4}$ exposure and that Egr-1 deficiency impairs this response.

The hepatic oval cell response is activated only in situations where liver injury is so severe that proliferation of existing hepatocytes is insufficient to rapidly reinstate normal liver function and/or when proliferation of hepatocytes is inhibited. ${ }^{38}$ Despite its hepatotoxicity, $\mathrm{CCl}_{4}$ exposure alone is not sufficient to promote oval cell activation. $^{27}$ To study the oval cell response in mice and rats, investigators combine two different agents: a hepatotoxin or 2/3 partial hepatectomy to induce liver injury and an antimitotic or DNA-damaging agent to inhibit hepatocyte proliferation. ${ }^{41,46-50}$ Aside from a single report that suggested an inconsistent and rare presence of cells with oval cell-like morphology in liver parenchyma after $\mathrm{CCl}_{4}$ exposure, ${ }^{51}$ the current study is the first to fully characterize a robust activation of the oval cell response in mice using $\mathrm{CCl}_{4}$ in the absence of exogenous inhibitors of hepatocyte proliferation.

We hypothesize that more severe liver injury in the egr-1 ${ }^{-1-}$ mice after acute $\mathrm{CCl}_{4}$, (unpublished data), coupled with an attenuation or delay of hepatocyte proliferation, is responsible for activation of the oval cell response in egr-1-1- mice observed in the current study. Expression of cytokines, TNF $\alpha$, IL6, and the complement activation products $\mathrm{C} 3 \mathrm{a}$ and $\mathrm{C} 5 \mathrm{a}$, are required to induce hepatoprotection and proliferative competence in hepatocytes after $\mathrm{CCl}_{4}$ exposure or partial hepatectomy. ${ }^{52-56}$ TNF $\alpha$ expression was reduced in livers from egr-1 ${ }^{-1-}$ mice after acute $\mathrm{CCl}_{4}$, exposure (unpublished data). This is associated with attenuated bromodeoxyuridine incorporation (Pritchard and Nagy, manuscript in preparation) and suggests a negative impact of reduced TNF $\alpha$ expression on liver regeneration in egr-1 $1^{-1-}$ mice. After partial hepatectomy, Liao et al demonstrated attenuated hepatocyte proliferation in egr-1 $1^{-1-}$ mice and identified reduced expression of $\mathrm{Cdc} 20$, a protein required for the anaphase promoting complex and successful mitosis, as the explanation for reduced hepatocellular proliferation. ${ }^{20}$ In that study, Egr-1 deficiency delayed hepatocyte proliferation but did not prevent liver regeneration. ${ }^{20} \mathrm{Im}$ portantly, activation of the oval cell response was not noted. Unlike the single cycle of liver injury and repair induced after partial hepatectomy, the iterative injury and 
fibrosis induced by chronic $\mathrm{CCl}_{4}$ is likely critical for oval cell activation in egr-1 $1^{-1-}$ mice.

Collectively, the data in this report suggest that Egr- 1 is an important negative regulator of hepatic fibrosis and oval cell activation; the specific mechanisms of which remain to be elucidated. The aberrant response to tissue injury in egr-1 $1^{-1-}$ mice is likely initiated by reduced hepatic inflammation early in the response to $\mathrm{CCl}_{4}$ exposure (unpublished data) and supplemental Figure S4 (http:// ajp.amjpathol.org). Reduced inflammation is then associated with a cascade of events promoting more severe liver injury and reduced hepatic wound healing. The cumulative result of dysregulated hepatic wound healing in egr-1 $1^{-1-}$ mice was enhanced fibrosis and activation of the oval cell response. In this genetic model, attenuated inflammation and wound healing promoted hepatic fibrosis. Therefore, caution should be applied when developing new strategies to eliminate early inflammatory processes, such as increased TNF $\alpha$, in response to injury to attenuate fibrosis. Maintaining the normal inflammatory response, rather than eliminating it, is critical for normal wound-healing. Indeed, the current data, as well as our recently reported data (unpublished data), support the hypothesis that precisely orchestrated induction and resolution of hepatic inflammation is a prerequisite for normal execution of hepatic wound healing and that Egr-1 is a critical regulator of this process.

\section{Acknowledgments}

We acknowledge the technical assistance and animal husbandry expertise of Megan R. McMullen, Emmanuelle Ogier, and Brian T. Pratt. Special thanks to Gavin Arteel and Claudia von Montfort for help with $\mathrm{CCl}_{4}$ mouse model. We also thank Dr. Valentina Factor $(\mathrm{NIH} / \mathrm{NCl})$ for the kind gift of the A6 antibody and Dr. Belinda Knight for guidance with hepatic A6 immunolocalization.

\section{References}

1. Hantash BM, Zhao L, Knowles JA, Lorenz HP: Adult and fetal wound healing. Front Biosci 2008, 13:51-61

2. Henderson NC, Iredale JP: Liver fibrosis: cellular mechanisms of progression and resolution. Clin Sci (Lond) 2007, 112:265-280

3. Friedman SL: Mechanisms of hepatic fibrogenesis. Gastroenterology 2008, 134:1655-1669

4. Fowell AJ, Iredale JP: Emerging therapies for liver fibrosis. Dig Dis 2006, 24:174-183

5. Gashler A, Sukhatme VP: Early growth response protein 1 (Egr-1): prototype of a zinc-finger family of transcription factors. Prog Nucleic Acid Res Mol Biol 1995, 50:191-224

6. Yan SF, Fujita T, Lu J, Okada K, Shan Zou Y, Mackman N, Pinsky DJ, Stern DM: Egr-1, a master switch coordinating upregulation of divergent gene families underlying ischemic stress. Nat Med 2000, 6:1355-1361

7. Harja E, Bucciarelli LG, Lu Y, Stern DM, Zou YS, Schmidt AM, Yan SF: Early growth response-1 promotes atherogenesis: mice deficient in early growth response-1 and apolipoprotein E display decreased atherosclerosis and vascular inflammation. Circ Res 2004, 94: 333-339

8. Pawlinski R, Pedersen B, Kehrle B, Aird WC, Frank RD, Guha M, Mackman N: Regulation of tissue factor and inflammatory mediators by Egr-1 in a mouse endotoxemia model. Blood 2003, 101:39403947

9. McMullen MR, Pritchard MT, Wang Q, Millward CA, Croniger CM Nagy LE: Early growth response-1 transcription factor is essential for ethanol-induced fatty liver injury in mice. Gastroenterology 2005, 128:2066-2076

10. Pritchard MT, Roychowdhury S, McMullen MR, Guo L, Arteel GE, Nagy LE: Early growth response-1 contributes to galactosamine/ lipopolysaccharide-induced acute liver injury in mice. Am J Physiol Gastrointest Liver Physiol 2007, 293:G1124-G1133

11. Yao J, Mackman N, Edgington TS, Fan ST: Lipopolysaccharide induction of the tumor necrosis factor-alpha promoter in human monocytic cells. Regulation by Egr-1, c-Jun, and NF-kappaB transcription factors. J Biol Chem 1997, 272:17795-17801

12. McMahon SB, Monroe JG: The role of early growth response gene 1 (egr-1) in regulation of the immune response. J Leukoc Biol 1996 60:159-166

13. Maltzman JS, Carmen JA, Monroe JG: Transcriptional regulation of the Icam-1 gene in antigen receptor- and phorbol ester-stimulated $B$ Iymphocytes: role for transcription factor EGR1. J Exp Med 1996, 183:1747-1759

14. Grose R, Harris BS, Cooper L, Topilko P, Martin P: Immediate early genes krox-24 and krox-20 are rapidly up-regulated after wounding in the embryonic and adult mouse. Dev Dyn 2002, 223:371-378

15. Amendt C, Mann A, Schirmacher P, Blessing M: Resistance of keratinocytes to TGFbeta-mediated growth restriction and apoptosis induction accelerates re-epithelialization in skin wounds. J Cell Sci 2002, 115:2189-2198

16. Wu M, Melichian DS, de la Garza M, Gruner K, Bhattacharyya S, Barr L, Nair A, Shahrara S, Sporn PH, Mustoe TA, Tourtellotte WG, Varga $\mathrm{J}$ : Essential roles for early growth response transcription factor Egr-1 in tissue fibrosis and wound healing. Am J Pathol 2009, 175: 1041-1055

17. Thiel G, Cibelli G: Regulation of life and death by the zinc finger transcription factor Egr-1. J Cell Physiol 2002, 193:287-292

18. Braddock M: The transcription factor Egr-1: a potential drug in wound healing and tissue repair. Ann Med 2001, 33:313-318

19. Bryant M, Drew GM, Houston P, Hissey P, Campbell CJ, Braddock M: Tissue repair with a therapeutic transcription factor. Hum Gene Ther 2000, 11:2143-2158

20. Liao Y, Shikapwashya ON, Shteyer E, Dieckgraefe BK, Hruz PW, Rudnick DA: Delayed hepatocellular mitotic progression and impaired liver regeneration in early growth response-1-deficient mice. J Biol Chem 2004, 279:43107-43116

21. Yan SF, Zou YS, Gao Y, Zhai C, Mackman N, Lee SL, Milbrandt J, Pinsky D, Kisiel W, Stern D: Tissue factor transcription driven by Egr-1 is a critical mechanism of murine pulmonary fibrin deposition in hypoxia. Proc Natl Acad Sci U S A 1998, 95:8298-8303

22. Liu C, Rangnekar VM, Adamson E, Mercola D: Suppression of growth and transformation and induction of apoptosis by EGR-1. Cancer Gene Ther 1998, 5:3-28

23. Liu C, Calogero A, Ragona G, Adamson E, Mercola D: EGR-1, the reluctant suppression factor: eGR-1 is known to function in the regulation of growth, differentiation, and also has significant tumor suppressor activity and a mechanism involving the induction of TGFbeta1 is postulated to account for this suppressor activity. Crit Rev Oncog 1996, 7:101-125

24. Chen SJ, Ning H, Ishida W, Sodin-Semrl S, Takagawa S, Mori Y Varga J: The early-immediate gene EGR-1 is induced by transforming growth factor-beta and mediates stimulation of collagen gene expression. J Biol Chem 2006, 281:21183-21197

25. Haas TL, Stitelman D, Davis SJ, Apte SS, Madri JA: Egr-1 mediates extracellular matrix-driven transcription of membrane type 1 matrix metalloproteinase in endothelium. J Biol Chem 1999, 274:2267922685

26. Constandinou C, Henderson N, Iredale JP: Modeling liver fibrosis in rodents. Methods Mol Med 2005, 117:237-250

27. Fausto N, Campbell JS: The role of hepatocytes and oval cells in liver regeneration and repopulation. Mech Dev 2003, 120:117-130

28. Lee SL, Tourtellotte LC, Wesselschmidt RL, Milbrandt J: Growth and differentiation proceeds normally in cells deficient in the immediate early gene NGFI-A. J Biol Chem 1995, 270:9971-9977

29. Lee SL, Wang Y, Milbrandt J: Unimpaired macrophage differentiation 
and activation in mice lacking the zinc finger transplantation factor NGFI-A (EGR1). Mol Cell Biol 1996, 16:4566-4572

30. Pritchard MT, McMullen MR, Stavitsky AB, Cohen JI, Lin F, Medof ME, Nagy LE: Differential contributions of C3. C5, and decay-accelerating factor to ethanol-induced fatty liver in mice. Gastroenterology 2007 , 132:1117-1126

31. Engelhardt NV, Factor VM, Yasova AK, Poltoranina VS, Baranov VN, Lasareva MN: Common antigens of mouse oval and biliary epithelial cells. Expression on newly formed hepatocytes, Differentiation 1990, 45:29-37

32. Friedman SL: Hepatic stellate cells: protean, multifunctional, and enigmatic cells of the liver. Physiol Rev 2008, 88:125-172

33. Wong FW, Chan WY, Lee SS: Resistance to carbon tetrachlorideinduced hepatotoxicity in mice which lack CYP2E1 expression. Toxicol Appl Pharmacol 1998, 153:109-118

34. Ji B, Chen XQ, Misek DE, Kuick R, Hanash S, Ernst S, Najarian R, Logsdon CD: Pancreatic gene expression during the initiation of acute pancreatitis: identification of EGR-1 as a key regulator. Physiol Genomics 2003, 14:59-72

35. Kuhlmann WD, Peschke P: Hepatic progenitor cells, stem cells, and AFP expression in models of liver injury. Int J Exp Pathol 2006, 87:343-359

36. Petersen BE, Grossbard B, Hatch H, Pi L, Deng J, Scott EW: Mouse A6-positive hepatic oval cells also express several hematopoietic stem cell markers. Hepatology 2003, 37:632-640

37. Fausto N: Tweaking liver progenitor cells. Nat Med 2005, 11: 1053-1054

38. Bird TG, Lorenzini S, Forbes SJ: Activation of stem cells in hepatic diseases. Cell Tissue Res 2008, 331:283-300

39. Gressner OA, Gressner AM: Connective tissue growth factor: a fibrogenic master switch in fibrotic liver diseases. Liver Int 2008, 28:1065-1079

40. Pi L, Oh SH, Shupe T, Petersen BE: Role of connective tissue growth factor in oval cell response during liver regeneration after 2-AAF/PHx in rats. Gastroenterology 2005, 128:2077-2088

41. Santoni-Rugiu E, Jelnes $P$, Thorgeirsson SS, Bisgaard HC: Progenitor cells in liver regeneration: molecular responses controlling their activation and expansion. Apmis 2005, 113:876-902

42. Nakamura H, Isaka Y, Tsujie M, Rupprecht HD, Akagi Y, Ueda N, Imai E, Hori M: Introduction of DNA enzyme for Egr-1 into tubulointerstitial fibroblasts by electroporation reduced interstitial alpha-smooth muscle actin expression and fibrosis in unilateral ureteral obstruction (UUO) rats. Gene Ther 2002, 9:495-502

43. Zhan SS, Jiang JX, Wu J, Halsted C, Friedman SL, Zern MA, Torok NJ:
Phagocytosis of apoptotic bodies by hepatic stellate cells induces NADPH oxidase and is associated with liver fibrosis in vivo. Hepatology 2006, 43:435-443

44. Cyrendorzhiev DD, Kutina SN, Zubakhin AA: Liver resistance to toxic effects of $\mathrm{CCl}(4)$ under conditions of gadolinium chloride depression of Kupffer cells. Bull Exp Biol Med 2000, 129:605-607

45. Mitchell C, Couton D, Couty JP, Anson M, Crain AM, Bizet V, Renia L, Pol S, Mallet V, Gilgenkrantz H: Dual role of CCR2 in the constitution and the resolution of liver fibrosis in mice. Am J Pathol 2009, 174:1766-1775

46. Alison M, Golding M, Lalani el N, Sarraf C: Wound healing in the liver with particular reference to stem cells. Philos Trans R Soc Lond B Biol Sci 1998, 353:877-894

47. Petersen BE, Zajac VF, Michalopoulos GK: Hepatic oval cell activation in response to injury following chemically induced periportal or pericentral damage in rats. Hepatology 1998, 27:1030-1038

48. Wang X, Foster M, Al-Dhalimy M, Lagasse E, Finegold M, Grompe M: The origin and liver repopulating capacity of murine oval cells. Proc Natl Acad Sci U S A 2003, 100:11881-11888

49. Akhurst B, Croager EJ, Farley-Roche CA, Ong JK, Dumble ML, Knight B, Yeoh GC: A modified choline-deficient, ethionine-supplemented diet protocol effectively induces oval cells in mouse liver. Hepatology 2001, 34:519-522

50. Factor VM, Radaeva SA, Thorgeirsson SS: Origin and fate of ova cells in dipin-induced hepatocarcinogenesis in the mouse. Am $J$ Pathol 1994, 145:409-422

51. Engelhardt NV, Baranov VN, Lazareva MN, Goussev Al: Ultrastructural localisation of alpha-fetoprotin (AFP) in regenerating mouse liver poisoned with CCL4. 1. Reexpression of AFP in differentiated hepatocyte. Histochemistry 1984, 80:401-407

52. Taub R: Liver regeneration: from myth to mechanism. Nat Rev Mo Cell Biol 2004, 5:836-847

53. Fausto N, Campbell JS, Riehle KJ: Liver regeneration. Hepatology 2006, 43:S45-S53

54. Strey CW, Markiewski M, Mastellos D, Tudoran R, Spruce LA, Greenbaum LE, Lambris JD: The proinflammatory mediators C3a and C5a are essential for liver regeneration. J Exp Med 2003, 198:913-923

55. Markiewski MM, Mastellos D, Tudoran R, DeAngelis RA, Strey CW, Franchini S, Wetsel RA, Erdei A, Lambris JD: C3a and C3b activation products of the third component of complement (C3) are critical for normal liver recovery after toxic injury. J Immunol 2004, 173:747-754

56. Markiewski MM, DeAngelis RA, Strey CW, Foukas PG, Gerard C Gerard N, Wetsel RA, Lambris JD: The regulation of liver cell survival by complement. J Immunol 2009, 182:5412-5418 